\title{
Editorial: Fé e Política
}

\author{
Editorial: \\ Faith and Politics
}

\section{Paulo Fernando Carneiro de Andrade}

A questão da relação entre a Fé Cristã e o agir dos cristãos na sociedade permeia toda a história do cristianismo. Mais especificamente na América Latina esta questão se desdobra na reflexão teológica entre Fé e Política. Nos últimos tempos, a ação organizada de cristãos de diferentes denominações no campo político tornou ainda mais urgente aprofundar esta reflexão hoje.

Muitas vezes esta relação tem tomado formas que já se supunham ultrapassadas, apoiadas em interpretações fundamentalistas, que não reconhecem os fundamentos do Estado Democrático de Direito e que por meio da ação política de uma parcela de cristãos tentam impor através de leis, de processos administrativos ou do puro exercício do poder, restrições ilegítimas à liberdade dos cidadãos e a necessária pluralidade que compõe as sociedades contemporâneas.

Neste contexto deve-se recordar as palavras do Papa Paulo VI na Carta Apostólica Octogesima Adveniens:

A ação política - será necessário acentuar que se trata prevalentemente de uma ação e não de uma ideologia? - deve ter como base de sustentação um esquema de sociedade, coerente nos meios concretos que escolhe e na sua inspiração, que deve alimentar-se numa concepção plena da vocação do homem e das suas diferentes expressões sociais. Não compete nem ao Estado, nem sequer aos partidos políticos, que estariam fechados sobre si mesmos, procurar impor uma ideologia, por meios que viessem a redundar em ditadura dos espíritos, a pior de todas. É sim aos grupos culturais e religiosos - salvaguardada a liberdade 
de adesão que eles pressupõem - que assiste o direito de, pelas suas vias próprias e de maneira desinteressada, desenvolverem no corpo social essas conviç̧ões supremas acerca da natureza, da origem e do fim do homem e da sociedade. Neste ponto, é oportuno recordar o princípio proclamado no recente Concílio Vaticano II: “A verdade não se impõe de outro modo senão pela sua própria força de verdade, que penetra nos espíritos, ao mesmo tempo suave e fortemente [Dignitatis Humanae 1]". ${ }^{1}$

Se a posição fundamentalista não pode ser aceita, isto não significa que os cristãos não devam participar ativamente da política, de um outro modo. Nos dias atuais o Papa Francisco tem enfatizado em seu Magistério a dimensão social da fé cristã, denunciando em sua encíclica Laudato Si a existência de uma aguda crise sócio ambiental que tem como raiz um sistema econômico que se tornou mundial e que produz exclusão, morte e a destruição da Natureza. ${ }^{2}$ Diante disto os cristãos tem o dever, a partir de sua fé, em diálogo com todos os homens e mulheres de boa vontade, de atuar na sociedade contra as causas que se encontram na raiz desta crise, para que esta seja superada de modo que a humanidade possa ter um futuro conforme os desígnios do Criador. ${ }^{3}$

Esta nova urgência da questão Fé e Política motivou nossa Revista a dedicar este número a este tema através da constituição de um dossiê "Fé e Política" que acolhe diversas contribuições sobre o tema, a partir de diferentes perspectivas.

Deste modo esperamos que este volume possa ser uma contribuição significativa ao debate atual sobre a relação entre o Cristianismo e a Sociedade.

\section{Referências bibliográficas}

FRANCISCO, PP. Carta Encíclica Laudato Si' sobre o cuidado da casa comum. Disponível em: <http://www.vatican.va/content/francesco/pt/ encyclicals/documents/papa-francesco_20150524_enciclica-laudato-si. html>. Acesso em: 19 nov. 2020.

PAULO VI, PP. Carta Apostólica Octogesima Adveniens por ocasião do

\footnotetext{
${ }^{1}$ OA 25, grifos nossos.

${ }^{2}$ LS 17-51.

${ }^{3}$ LS 228-232.
} 
80 ${ }^{\circ}$ aniversário da Encíclica Rerum Novarum. Disponível em: $<$ http:// www.vatican.va/content/paul-vi/pt/apost_letters/documents/hf_p-vi_ apl_19710514_octogesima-adveniens.html>. Acesso em: 19 nov. 2020.

Paulo Fernando Carneiro de Andrade

Doutor em Teologia pela Pontificia Università Gregoriana Docente do Departamento de Teologia da Pontifícia Universidade Católica do Rio de Janeiro Rio de Janeiro / RJ - Brasil E-mail:paulof@puc-rio.br 